\title{
MOTIVATION OF UNIVERSITY STUDENTS AS FUTURE ENTREPRENEURS
}

\author{
Peter Marinič, Viliam Záthurecký, Ondřej Špičák
}

\begin{abstract}
This paper looks at the issue of motivating individuals entering into the business environment through the establishment of new businesses. The paper has been inspired by findings from the analysis of secondary data, in particular from questionnaire surveys carried out by renowned institutions in both the Czech Republic and across Europe. Attention is then focused on students from Masaryk University who are expected to enter the business environment. The questionnaire survey was aimed at students from the Faculty of Economics and Administration, as well as students from the Faculty of Law. The results are an important output for developing further methods in terms of their practical application in improving the preparation of students for their future careers.
\end{abstract}

\section{Keywords}

Motivation, demotivation, motivational factors, demotivational factors, establishment of new businesses, potential entrepreneur, start-up enterprises

\section{Introduction}

At present the European Union is faced with significant problems which could affect its future. If we leave aside increased tension due to Russian policies, there is also pressure on the European Union's labour market, particularly among young people up to the age of 25, with some five million unemployed according to Eurostat. There are also many refugees settling in Europe, and after their integration into society this can add to the level of youth unemployment. This means that at least every fifth young person on the labour market is not and will not be able to find employment. The labour market, both in the Czech Republic and other countries, is not able to absorb sufficiently quickly the influx of a new workforce, consisting not only of fresh graduates from schools and universities, but also people without an education or with an apprenticeship. One particularly negative phenomenon across Europe is the predominance of graduates from the humanities who have a general education rather than a career-specific one. The overall level of unemployment for people up to the age of 25 has more than doubled in recent years - in the third quarter of 2014 the EU average was $23.0 \%$.[8]

According to Eurostat, in the Czech Republic the level of unemployment among people up to 25 is between $17.6 \%$ and $19.6 \%$. The highest level of youth unemployment is in Greece and Spain (over 50\%) and in Italy (circa 37\%), a situation which could be exacerbated by immigration. In the Czech Republic the level of youth unemployment remains below the EU average (19.6\%), though it is still higher than the overall level of unemployment in the CR.

It is the youngest section of the workforce which will be behind any future economic growth and innovation and, mostly importantly, will provide resources for the future. That is why it is 
crucial to offer support to this section of the population and the young people who are studying at secondary schools and universities, as well as those undertaking apprenticeships. The notion that this support should be mainly directed towards unemployed young people must be refuted.

It is our belief that waiting until young people are unemployed before offering them support is the wrong course of action. This is dealing with the effects and not the causes of this adverse situation, and is therefore a non-conceptual and unsystematic solution.

It is the duty of the state, schools and institutions to acquaint future graduates from all different types of schools with issues related to the labour market in good time and, alongside their specialist knowledge and soft skills, provide them with the information and skills which will enable them to be successful on the labour market. This should entail a proper evaluation of their own skills, presentation options and realistic ideas about the working environment and the nature of the work that future graduates will encounter in their specialist field or profession.

At present, plenty of scope has opened up for establishing new businesses in the form of start-ups. Any available means and methods for honing students' practical skills during their studies will help significantly to ease the transition to the labour market for all types of future graduates, while reducing the risk of long-term unemployment at the start of their professional careers. Prolonging studies or returning to studying can be a way to combat passivity through the alternative of education and upskilling, though often this is only an escape from a particular situation and one's own responsibilities, and it can be a waste of both the state's and the student's time and resources.

Therefore, one crucial step is to change the paradigm of the younger generation and ideas about employment so that becoming self-employed through a start-up is considered a normal and standard alternative to ordinary employment.

Thus the fundamental idea for the conducted research is to identify tendencies for the selfemployment among students as potential future entrepreneurs. It is our hope to find out if there is motivation for such activity among university students, especially students of corporate economy and management or students of law. We presume that among these students there should be interest for future entrepreneurship, due to students study preferences. Our interest is to identify the most intensive motives and find out obstacles in the group of selected students. Thus we will be able to find out the answer if the students are rather responsible for their future employment, in for of self-employment, or prefers to be leaded by someone else in their future employment. The results will be background for preparation of materials for future education process as well.

\section{Theoretical Background to the Research}

Businesses represent the materialization of human activities of an entrepreneurial nature. As with any other activity carried out by individuals, entrepreneurial activity comes about on the basis of certain internal factors or as a reaction to the surroundings.

As an expression of economic activity, entrepreneurship can be viewed in various ways. ${ }^{1}$

1 Entrepreneurship can be regarded as the process of establishing and managing a business (a layman's view); on the other hand, the definition can also include any activities which serve to develop an entrepreneurial spirit, approaches and skills, and can thus cover a wide variety of areas from start-ups to product development to business development and innovation.[9] 
From a practical perspective it is possible to use the definition of entrepreneurship provided by the European Commission: "Entrepreneurship is the mindset and process to create and develop economic activity by blending risk-taking, creativity and/or innovation with sound management, within a new or an existing organization." [12] With regard to the use of secondary data and the form of analyses carried out as part of the Global Entrepreneurship Monitor, it is also useful to add the definition of entrepreneurship as "any attempt to establish a new business or new economic entity, such as self-employment, creating a new business or expanding an existing one, carried out by an individual, a team of individuals or an established company."[14] This definition is quite broad and thus avoids the differences in the definition of entrepreneurship in various countries, allowing comparisons of business activities across the globe.

In this respect, the entrepreneur can thus be seen as the implementer of entrepreneurial activity. For an approximate definition of entrepreneur we can turn to Czech legislation. As stated in $\$ 420$ of the new Civil Code, an entrepreneur is considered to be someone who "independently carries out gainful activity on his own account and liability under a trade license or with the intention of systematically pursuing this activity to make a profit."'[3] Therefore, the pursuit of profit is an important motivator, which is emphasized by the legislative concept of entrepreneurial activities. It also corresponds to the idea of businesses as organised economic entities whose main objective from the perspective of corporate management is the maximization of profit.

On the other hand, a narrow view of entrepreneurship as being motivated only by the idea of making or maximizing profit, which also views the entrepreneur as an individual focused solely on profit-making, is not sufficiently comprehensive from the perspective of analyzing individuals' motivation for establishing new businesses or entering into the business environment. Such a narrow view could lead to invalid conclusions, particularly from the perspective of attempting to create suitable methods of developing an educational programme at university level and preparing potential entrepreneurs.

For these reasons it is necessary to look more closely at the motivation of individuals, particularly with regard to their potential to become entrepreneurs, i.e. at the motivation to establish new businesses and enter the business environment. That is why it is necessary to take a broader view of the motivation for entrepreneurship - from both theoretical and practical perspectives.

The concept of motivation has its origins in Latin. It is derived from the Latin word movere, meaning to move. In other words, motivation is something which impels (moves) someone to do something. [4] Motivation is the "dynamic system of internal motives for activity (or inactivity) by an individual, which determines his behaviour and feelings."[7] It expresses the dynamics of an individual and is dependent on changing circumstances. [15] Motivation can be defined as a set of internal driving forces which point people in a certain direction, stimulate them to act and maintain the resulting activity.[16] Motivation is, therefore, expressed by the motives which people have for starting their business activity and what they expect from this activity.

Motives are closely linked to motivation. A motive is defined as the cause of a particular phenomenon (a need, interest, ideal, set of values, etc.) We can, therefore, consider a motive

2 The new Civil Code paraphrases the definition of entrepreneurship as set out in Act no. 513/1991 Coll. of the Commercial Code in section 2, that "entrepreneurship is understood to be systematic activity which is independently carried out for the purpose of making a profit by an entrepreneur in his own name and his own liability."[2] 
to be the basic unit of motivation. Although needs are regarded as the most important of the motives (see, for example, Maslow's theory of needs), behaviour is almost always influenced by a set of motives. Therefore, a commonly used definition of motivation is that of a complex of motives which is a resultant acting on and influencing human behaviour in a given situation. [15]

Motivation has three functions in human behaviour:

- it regulates conduct and behaviour,

- it organizes conduct and behaviour,

- it stimulates and activates individual behaviour.[15]

A great deal of research has been carried out, particularly abroad, into the motivation for establishing a business. [1] A standard and widely accepted division of the theories which describe in general terms the reasons or factors which prompt a potential entrepreneur to set up a business is the division in the theories of push and pull motivators.

These theories divide the motives for entrepreneurship into two groups. Individuals start to do business either because they have no other option, for example due to long-term unemployment, or because they sense an opportunity to make a profit. These two situations gave rise to the concepts of push theory and pull theory, or necessity entrepreneurship and opportunity entrepreneurship. [6]

Push theory is based on the fact that individuals are "pushed" into entrepreneurship due to the negative circumstances in which they find themselves. It is the result of the conflict between the present situation which individuals find themselves in and the situation which they would like to be in. [11] Motives are described as internal factors or forces. Examples of negative circumstances and situations are loss of employment, long-term unemployment, poor wages or unsatisfactory working conditions.

Pull theory is based on motives which "draw" individuals and encourage them to intensify their entrepreneurial efforts. They often take the form of attractive incentives and can be termed external forces. In most cases this involves recognizing an opportunity or a gap in the market, etc.

Although these individual motivational factors can be recognised and identified as push or pull factors, there is widespread agreement that the resulting motivation is a combination of push and pull motives operating at the same time, not entirely separate and independently functioning realities.[13] Push motivators relate more to the internal and emotional aspects of an individual, while pull motivators are linked to external aspects which originate from a given situation and its subjective perception.[21]

In the case of motivation, "push" causes may be stronger, but their effect is short-lived. As a rule, they do not produce exceptional results. "Pull" causes are more enduring and rarely cease to operate entirely. It is these causes which outstanding entrepreneurs base their success on. [20] Research also shows that so-called pull entrepreneurs are more successful than push entrepreneurs. [5] The personal characteristics of individual entrepreneurs also confirm this. Necessity entrepreneurs tend to be older, less well-educated, have less experience and are worse at recognizing future opportunities. On the other hand, entrepreneurs who have sensed the right opportunity (opportunity entrepreneurs) exhibit higher profits. [18] Studies also show that opportunity entrepreneurs contribute more to economic growth, innovation and job creation. [17] 


\section{Research Methodology}

The research into the motivation for establishing new businesses and entering the business environment can be divided into two stages. In the first stage a questionnaire survey was carried out on students of economics only, and in the second stage the questionnaire survey was extended to law students too.

The first stage of the questioning was part of the research project "Analysis of the Potential of Trainee Entrepreneurs", aimed at identifying motives and anticipated problems in the establishment of new businesses. This questionnaire survey was directly inspired by a similar questionnaire survey carried out by Eurostat in 2005. [10][19]

The questionnaire was sent to 246 students of the selected subjects, with a total of 66 completed questionnaires being returned. Therefore, the response rate $(26.8 \%)$ can be judged sufficient for arriving at meaningful conclusions, at least from the perspective of students of business economics and management, the guarantor of which is the Department of Corporate Management at Masaryk University's Faculty of Economics and Administration. [22]

The questionnaire survey was aimed at problems which might be encountered by entrepreneurs setting up new businesses, the reasons for going into business and the preferred means of financing when setting up new businesses. Another integral part of the survey was the profile of the person entering the business environment in terms of gender and previous experience of entrepreneurial activities.

The second stage of the questionnaire survey ${ }^{3}$ was carried out at the beginning of 2015 on students from the Faculty of Economics and Administration and the Faculty of Law at Masaryk University. The inspiration for the questionnaire survey came from the results of a questionnaire survey by Eurostat, Global Entrepreneurship Monitor and Global Entrepreneurship Index. The data collection resulted in 42 fully completed questionnaires being returned. The rate of return for the questionnaire cannot be determined due to its viral dissemination, which makes it impossible to determine the total population.

The questions within the questionnaire were designed to ascertain the respondents' characteristics, their current involvement in business activities, their potential future interest in entrepreneurship and their preferred legal form or sector. Subsequently, questions about entrepreneurial motivators were included.

On the one hand, it is possible to object that this type of questionnaire survey is too restricted and its results too inconclusive to provide generalizations, that in essence there is no sense in carrying out such a questionnaire survey. There is justification for this approach, limited to a single institution, particularly with regard to the use of the information acquired in further educational training and other activities leading to the support of young people as potential entrepreneurs or managers. On the other hand, if it is reasonable to expect that the preconditions for establishing new businesses will exist with some graduates of the higher-education system, then this will also be the case with university students studying economics and law. This applies in particular to the students participating in both parts of the questionnaire survey, mainly due to the students' backgrounds and their focus on issues connected with entrepreneurship and entrepreneurial activities, which naturally include the establishment of new businesses.

3 This questionnaire and its evaluation were also part of Ondřej Špičák’s Bachelor studies. 


\section{Results of the First Survey}

As part of the first stage of the questionnaire, the results were compared with those from the questionnaire survey carried out by Eurostat. The aim of this comparison was to determine whether the individual factors affecting the establishment of new businesses at the level of the survey for students from the Department of Corporate Management at the Faculty of Economics and Administration of Masaryk University corresponded with the results obtained from participants from across the Czech Republic in the Eurostat survey. If the results differ for any of the factors, then it is necessary to explain these differences or to determine whether they might form the basis for further, more specific research.

The breakdown of participants by gender is shown in Graph 1. The survey carried out by Eurostat involved 62,400 active participants in the survey. In the survey carried out by the Faculty of Economics and Administration, there were 66 actively participating respondents. The gender distribution of participants for the whole of the Czech Republic confirmed the generally acknowledged fact that more men than women are involved in setting up new businesses. Specifically, this ratio was $72.6 \%$ male to $27.4 \%$ female. However, with the students this ratio was reversed somewhat in favour of women (59.1\%) as opposed to men (40.9\%). This difference in representation was probably caused by the slight deviation in the ratio between men and women in the basic set, and although the distribution in the Czech population is roughly equal, among the students who cooperated it was women who predominated.

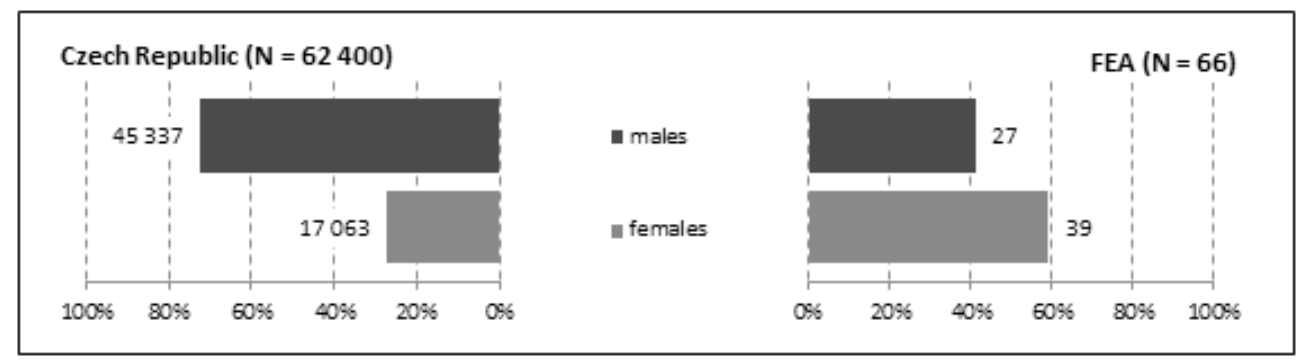

Source: Factors of Business Success statistics, Eurostat, 2005; Survey, FEA, 2014 [10][22]

\section{Graph 1: Gender distribution of the participants}

Among the participants in the Eurostat survey, $15.2 \%$ of those actively participating had experience of managing an enterprise. A similar figure was also identified with the students (17.9\%). This means that the dominant group consists of individuals without prior entrepreneurial experience. Therefore, an interest can be assumed in information concerning business activities, legal knowledge, financial literacy, negotiating skills, business skills, communication skills and other entrepreneurial activities, both for students and the overall population. 


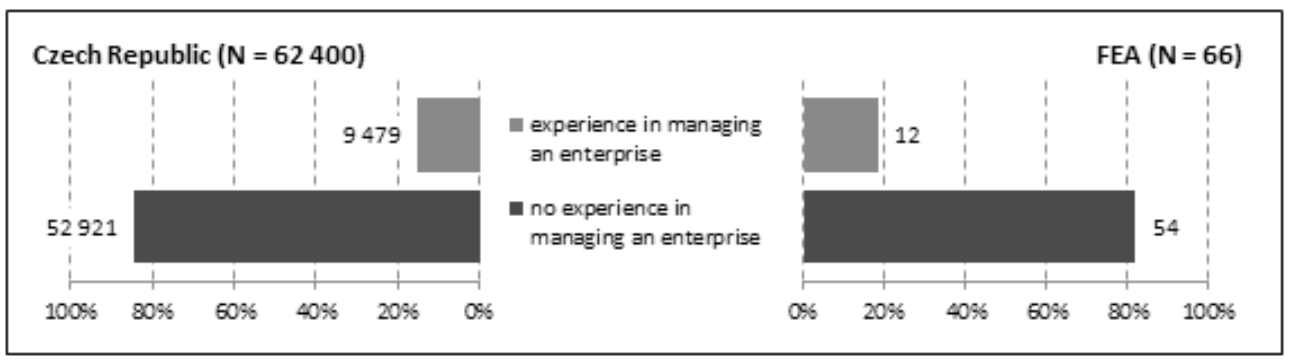

Source: Factors of Business Success statistics, Eurostat, 2005; Survey, FEA, 2014 [10][22]

\section{Graph2: Distribution of the participants according to experience in managing an enterprise}

As regards motives for establishing new businesses, the desire to be one's own boss prevailed in both studies (Eurostat 30.2\%; FEA 35.1\%). This can perhaps be explained by the individualism and unwillingness to submit to authority that is prevalent among individuals interested in entrepreneurship. The second most important factor among participants was the desire for new challenges (27.5\%), while for students there was also the desire to turn their hobby into a money-making enterprise $(22.1 \%)$. According to the results, the least important factor was the personal space created by children growing up (Eurostat 4.9\%; FEA 4.6\%), which is understandable with the student group as the issue of offspring does not yet apply. A more surprising result was the low importance of an entrepreneurial tradition as a motivator for entrepreneurs (Eurostat 4.7\%; FEA 6.1\%). This might be a result of the relatively small base for generating a tradition of self-employment in families. Another point to bear in mind is that new businesses tend to be set up by individuals who have no entrepreneurial tradition in their family background, where there exists a desire to change this fact. The dominance of the other factors in motivation might also explain the low importance of entrepreneurial tradition in the family.

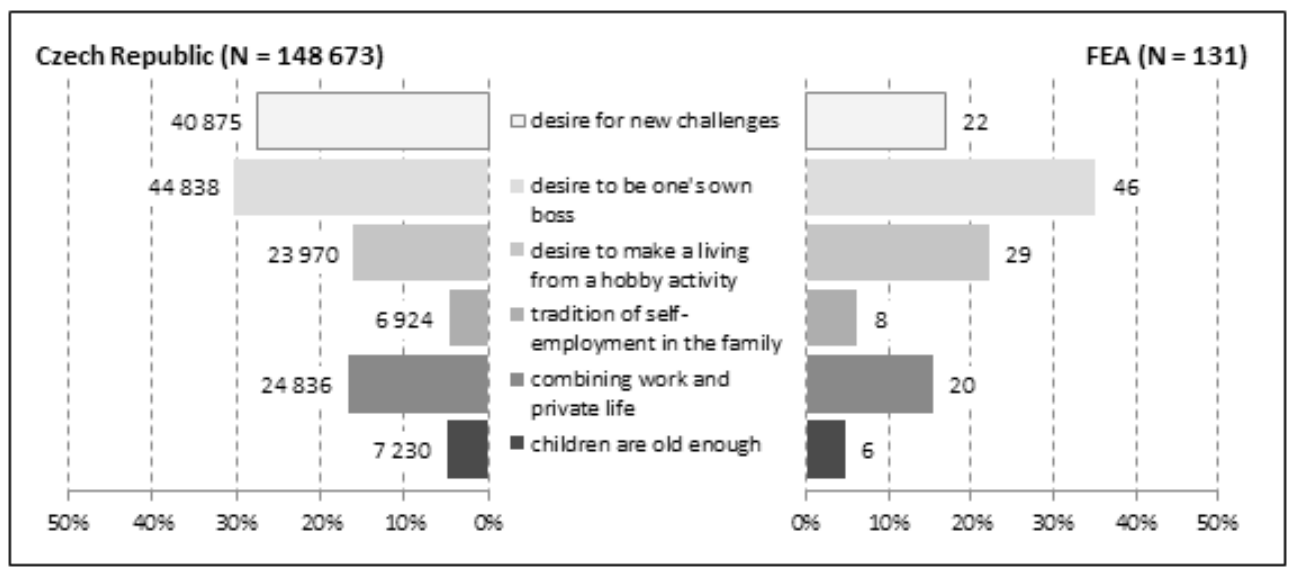

Source: Factors of Business Success statistics, Eurostat, 2005; Survey, FEA, 2014 [10][22]

Graph 3: Motivation of the participants for starting a new business (start-up) 
There are many issues which have to be tackled in connection with going into business. The most significant problems were identified as being the initial financing of the business (Eurostat 14.8\%; FEA 19.8\%) and the establishment of client networks (Eurostat 15.0\%; FEA 20.4\%). These problems might be considered common knowledge, which demonstrates the ability of the participants and students to rationally judge and assess problems in the preparatory phase of setting up a business. It is evidence of their basic soundness and orientation within the issue under discussion.

Problems concerning suppliers (Eurostat 5.3\%; FEA 1.2\%), suitable premises (Eurostat 6.7\%; FEA 2.4\%) the effective use of information technology (Eurostat 5.22\%; FEA 1.8\%) and receiving the backing of spouses or family (Eurostat 4.6\%; FEA 1.8\%) were viewed as less important. The most significant difference between participants and students in their perception of the problems was the issue of acquiring staff. For participants this issue came up less often $(4.5 \%)$, while with students this issue was perceived as more important in comparison with other problems perceived as "not so important" (6.6\%).

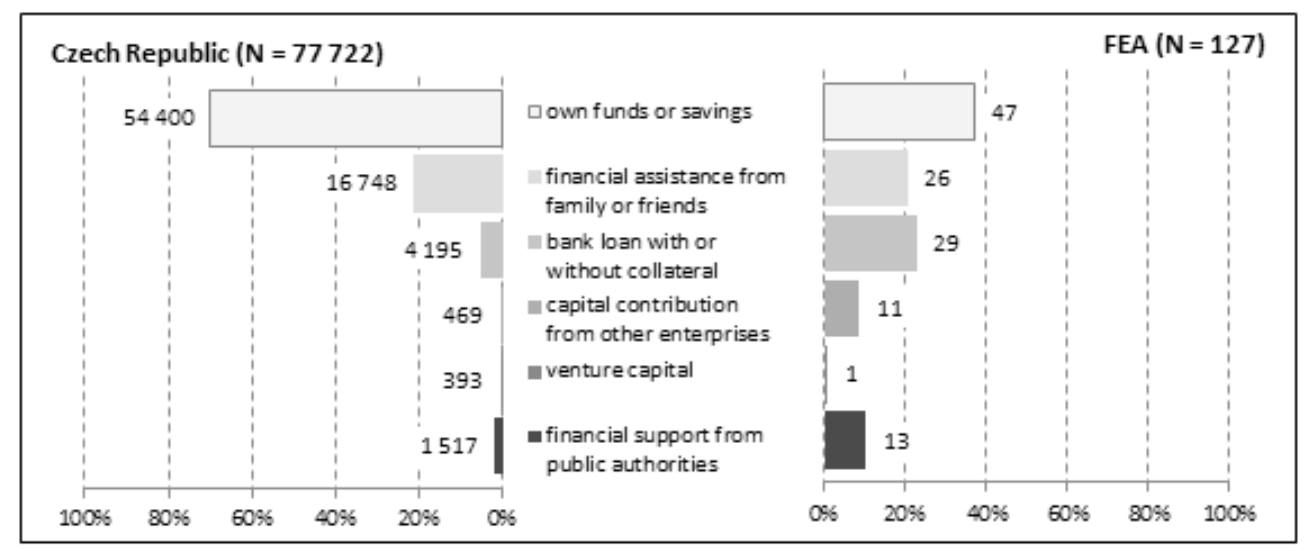

Source: Factors of Business Success statistics, Eurostat, 2005; Survey, FEA, 2014 [10][22]

\section{Graph 4: Problems expected when starting a new business}

A separate question concerned financing, which was also viewed as the biggest problem associated with going into business. The most commonly presented source of financing, and at the same time that with the largest difference between participants and students, was using one's own funds (Eurostat 70.0\%; FEA 37.0\%). It can be assumed that this difference comes from students' weaker economic position in comparison with the participants from the nationwide survey. It was further shown that in comparison with the participants, the students preferred bank loans, either with or without collateral (Eurostat 5.4\%; FEA 22.9\%), and finance from public authorities (Eurostat 2.0\%; FEA 10.3\%). The participants' and students' responses were almost identical for possible financial assistance for start-ups from family members or friends (Eurostat 21.6\%; FEA 20.5\%). 


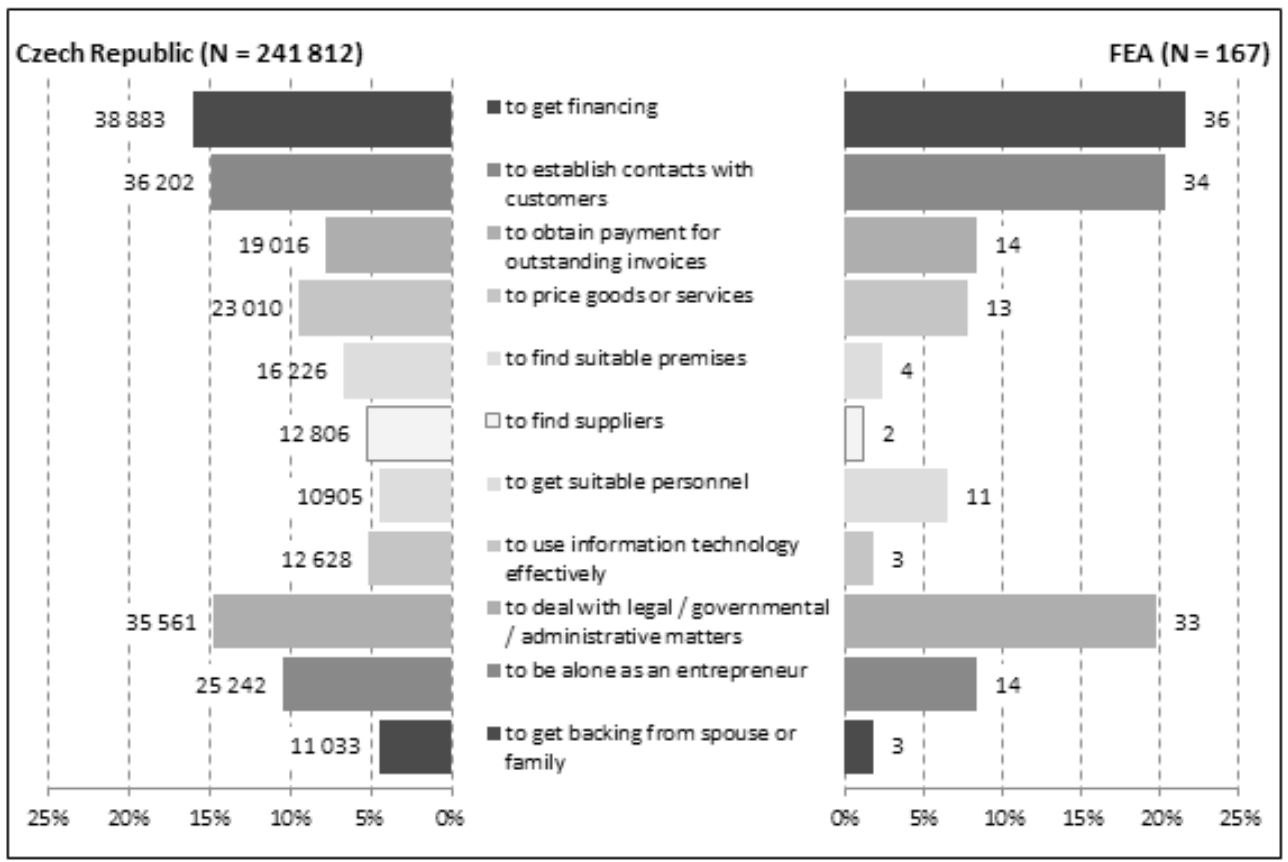

Source: Factors of Business Success statistics, Eurostat, 2005; Survey, FEA, 2014 [10][22]

\section{Graph 5: Method of financing a new business}

\section{Results of the Second Survey}

The second stage of the questionnaire survey was aimed at economics students from the Faculty of Economics and Administration and law students from the Faculty of Law at Masaryk University. The aim of the questionnaire survey was to identify the motivators for entrepreneurship based on the professional specialization of the students responding to the questionnaire survey.

The distribution of the students who actively participated in the second stage of the questionnaire survey was even, as is shown by the relevant graph. $40.5 \%$ of the students questioned study at the Faculty of Economics and Administration (FEA), which is the same figure as for the number of students from the Faculty of Law (FL). In addition, 19.0\% of the actively participating students study at both faculties.

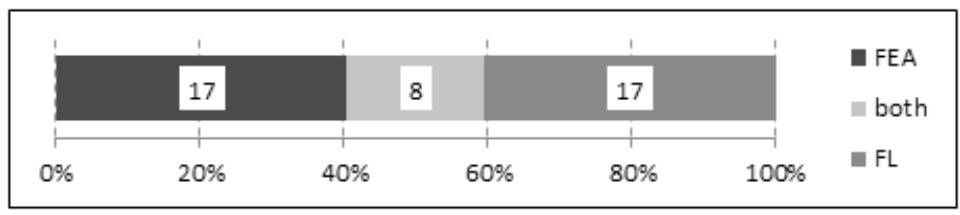

Source: Survey, FEA, 2015

Graph 6: Distribution of the respondents according to faculty 
Balanced results are also provided by a comparison of gender and the faculties. Of the students in the survey, $26.19 \%$ of women and $14.29 \%$ of men study at FL, while $21.43 \%$ of men and $19.05 \%$ of women study at FEA. $9.52 \%$ of men and $9.52 \%$ of women study at both faculties.

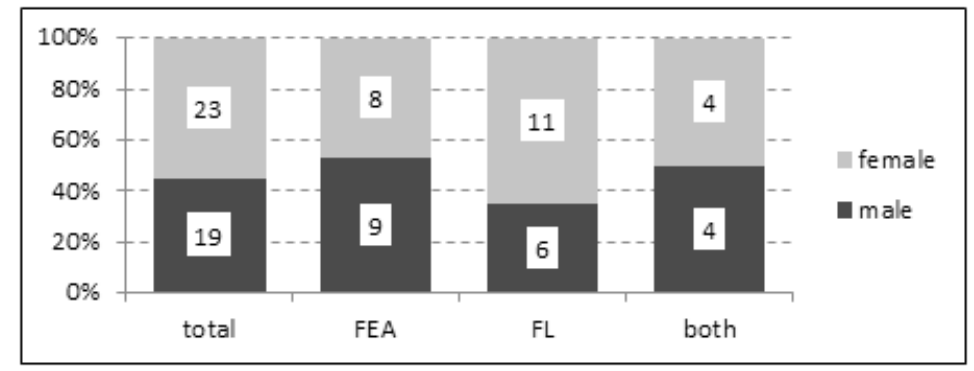

Source: Survey, FEA, 2015

\section{Graph 7: Gender distribution of the respondents according to faculty}

At the time when the questionnaire survey was carried out, $16.67 \%$ of the respondents were involved in business activities. Four of them were students from FL, two from FEA and one was from both faculties. Of the seven active entrepreneurs, only one was female. The remaining $83.33 \%$ of those questioned were not currently involved in business activities. This result was not surprising as students normally decide on their career further into their university education or after successfully completing their university studies.

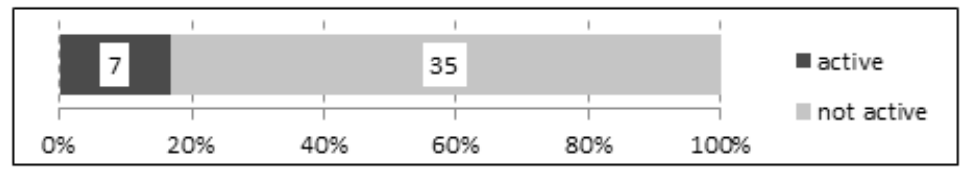

Source: Survey, FEA, 2015

\section{Graph 8: Distribution of respondents according to entrepreneurship activity}

For future or current entrepreneurship, most students favoured a capital company. $45.24 \%$ were in favour of this form of business, as represented by 7 students from FL, 6 students from FEA and 6 students from both faculties. The figure was similar for the self-employed category (42.86\%), which was chosen by 8 students from both FL and FEA and 2 students from both faculties. On the other hand, only one respondent from FEA and one student from both faculties opted for a personal company. Also included in the options was the possibility of doing business as an entity on the financial market; although this does not constitute a special form of entrepreneurship, it is such a specific activity that it was considered appropriate to mention this possibility. One respondent from FL and one from FEA chose this variant. There were 3 people who had not yet considered the legal form of their own entrepreneurship. 


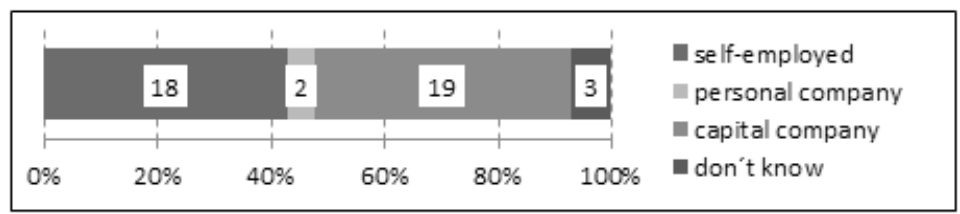

Source: Survey, FEA, 2015

\section{Graph 9: Potential legal forms of entrepreneurship}

When analyzing the question focused on research into the field in which students would like to do business, there was evidence of a trend amongst students from the law faculty to work in the branch they are studying. $40.48 \%$ of respondents (17) were considering a career in legal services and consultancy, with 10 of them studying at FL, 2 at FEA, and 5 at FEA and FL at the same time. To these should also be added one FL student who supplied his/her own alternative - advocacy. Among students of FEA, on the other hand, the sphere of trade in goods and services was the most common. This sector was chosen by $38.1 \%$ of respondents (16), of whom 8 attend FEA, 5 FL and 3 both faculties. The focus of the students questioned in terms of the other options for their future specialization in entrepreneurial activities is depicted in the relevant graph.

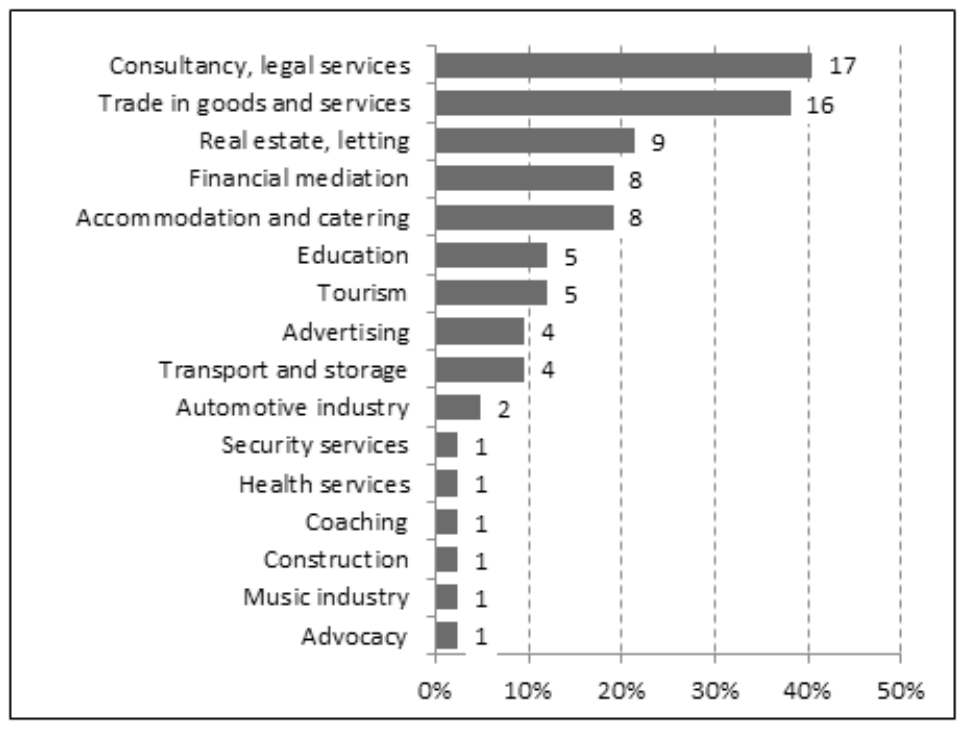

Source: Survey, FEA, 2015

\section{Graph 10: Area of potential desire for entrepreneurial activities}


The results of the questionnaire survey indicate that there is a strong prevalence of positive motivational factors - i.e. factors which enable trainee entrepreneurs to gain some benefit which they would not receive as an employee. The respondents thus have a clear view of the advantages of entrepreneurship as opposed to employment. The majority of those questioned (66.67\%) value the opportunity to make their own decisions about themselves and their time. This option was selected by 13 students of FL, 8 students of FEA and 7 students of both faculties. This confirms the findings of previous research, in which the desire to be one's own boss was identified as the most important factor. Nevertheless, the influence of motivation based on profit, as an important factor affecting motivation, also manifested itself within the questioning. It was identified as a motive by $64.3 \%$ of the students questioned. There was also evidence that because the law faculty steers its students towards legal practice, they have a clearer vision of their future career. Along with a statement of the motives for entering into the entrepreneurial sphere, the study also determined what emphasis is placed on these various motives by the individual students. The respondents were thus offered the option of putting the various factors in order of importance in deciding whether to enter into business. The average ranking of individual factors is given in brackets after the various options in the relevant graph. The importance of personal freedom is also confirmed by the average ranking of 4.656 , which represents the second lowest value. The highest values were found for the motive of potential profit (4.188). Profit and freedom of decision-making can therefore be ranked among the most significant positive factors which prompt students and graduates of FL and FEA to start up their own businesses.

The other motives which were given included motives based on inspiration from role models in the family $(21.4 \%)$, or continuing in a family tradition of entrepreneurship (11.9\%). Compared to role models, tradition is more stable and long-term; the family business often employs more members of the family and is passed on from generation to generation. When ranked according to the strength with which the motivational factor operates, family role models had an average position of 6.813 and family tradition an average position of 6.875 . Role models in the family can thus be considered a more powerful and more frequently operating motivational factor than entrepreneurship due to continuing in a family tradition.

The establishment of an innovative business was contemplated by $16.7 \%$ of students questioned. Here the trend amongst students from the law faculty who are headed for legal practice, in which there is not much scope for innovation, is once again evident. Innovative entrepreneurship was contemplated by only 2 students of FL. In contrast to this, 4 students of FEA with their general education in economics are not bound to a narrowly specialized branch, and so they can operate in almost any area. Nevertheless, innovation is not one of the main motivational factors for starting a business, which is also shown by the average ranking of 6.063.

The questionnaire survey confirms that students embark on entrepreneurship primarily from positive reasons and thanks to the advantages which it brings them in comparison with a normal work relationship. Only $4.76 \%$ of respondents are pushed into entrepreneurship due to the difficulty of finding employment (push motive). It can be assumed that during their period of study and shortly after its completion students consider entrepreneurship as an opportunity which they can take advantage of, not as a necessary variation on how to make a living. 


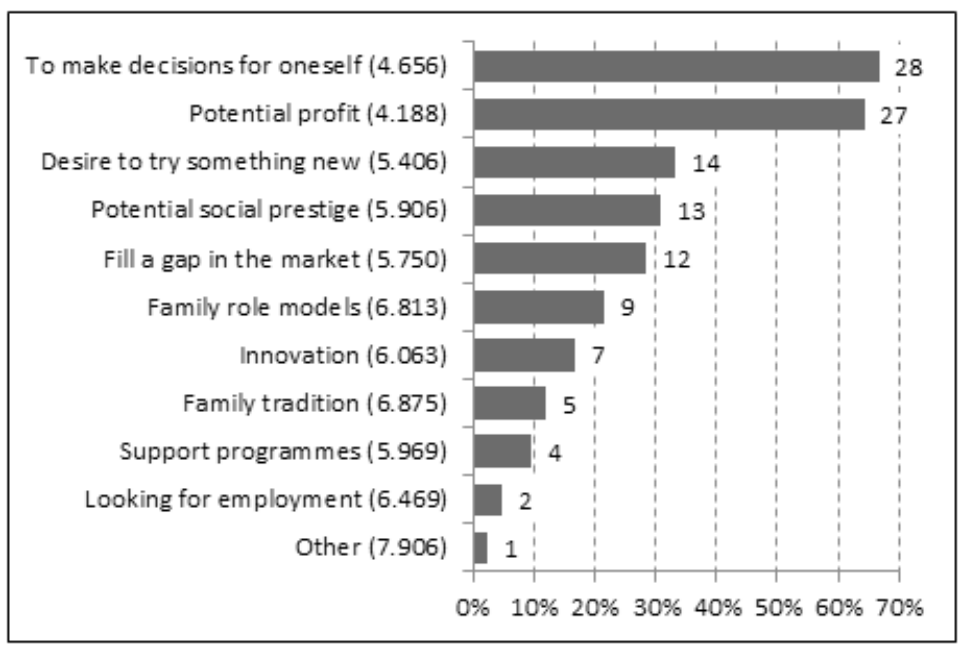

Source: Survey, FEA, 2015

\section{Graph 11: Motives for future entrepreneurship activities}

The next question focused on assessing the influences which deter students from entrepreneurship. These factors form an antithesis to the positive factors which the previous question examined. With this question the respondents could again choose multiple options at the same time, or they could supply their own answer. The results thus summarize the factors which, in the students' view, make starting a business more difficult and factors which discourage some people from entrepreneurship entirely. An answer expressing a complete lack of interest in entrepreneurship was also available. 


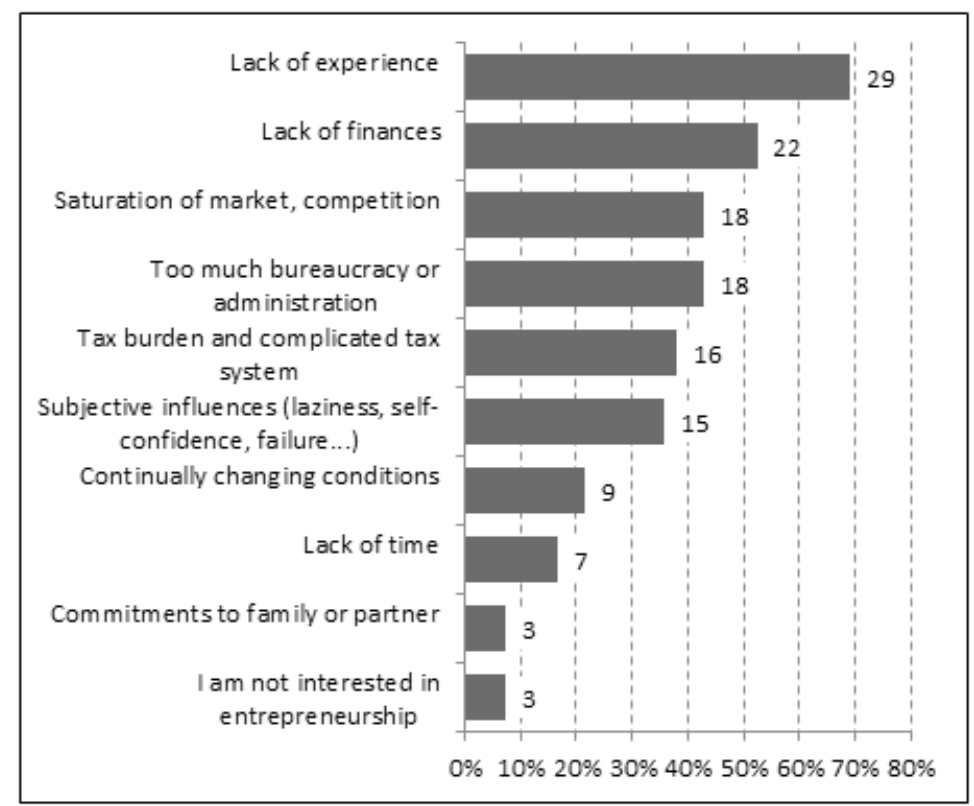

Source: Survey, FEA, 2015

\section{Graph 12: Problems of future entrepreneurship activities}

The biggest obstacle is considered by $69.05 \%$ of respondents to be a lack of personal experience in managing and running a business. It is clear from the previous questionnaire survey that only a minority of individuals have previous experience of running a business. Six of the respondents who consider a lack of experience to be an obstacle are already engaged in business.

Other significant problems for entrepreneurship are a lack of finances (52.38\%), obstacles in the form of a heavy administrative burden when setting up and managing a business (42.86\%), and the fear of competition and a saturated market (42.86\%). The problems perceived to be the most serious also include obstacles in the form of business taxation and a complicated tax system $(38.1 \%)$ and subjective influences such as laziness, lack of self-confidence or fear of failure $(35.71 \%)$.

As was the case in the preliminary research, in the study presented here family and obligations towards it do not play a significant role for respondents (7.14\%). Continually changing legislation and conditions for entrepreneurship are perceived as a problem $(21.43 \%)$. It is no surprise that students of the law faculty do not perceive this factor negatively, since a great many of them will make their living by consultancy in the field of legal services.

The final question related to forms of support provided. It examined what kind of support respondents envisage for their start-ups. Again, it was possible to choose more than one option at the same time, since in practice individual subsidies are not mutually exclusive. 


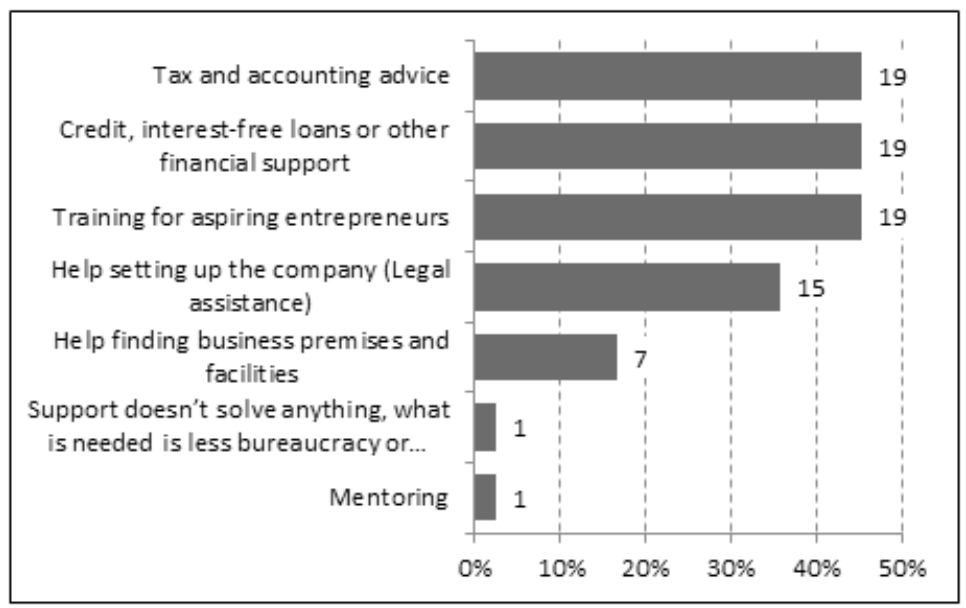

Source: Survey, FEA, 2015

\section{Graph 13: Area of potential support for entrepreneurship activities}

Respondents would appreciate training for new entrepreneurs (45.24\%; the individual reply by one respondent - mentoring - can also be assigned to this option), financial incentives in the form of credit, interest-free loans, etc. (45.24\%) or advisory services in the area of tax and accounting (45.24\%). It emerges from the research that training for new entrepreneurs would be particularly appreciated by women; men appear to be more self-confident and self-reliant. On the whole, however, training is valued more by students of FL, which may result from the absence of teaching of subjects linked with running and managing a business. On the other hand, students of FEA, especially women, would more often select legal assistance with setting up a business.

Relatively few of those questioned would like help finding suitable business premises (16.67\%). This may be related to the fact that the vast majority of those questioned plan to do business in non-manufacturing sectors, which are not particularly demanding in terms of specific premises and infrastructure. Finally, one respondent used the option of supplying his own answer and instead of direct support would appreciate the lowering or removal of negative factors which hinder entrepreneurship.

\section{Discussion of the results}

The issue of establishing new businesses, or the factors associated with setting up new businesses, can be perceived as an important area for the development of the economy and its ability to adapt itself to changing economic conditions. In the period since the economic and financial crisis, this issue has become even more important. From the point of view of educators working within major educational institutions in the field of economics, this also places certain demands on us in relation to shaping the new future generation of potential entrepreneurs. In this context, therefore, our duty is to investigate the current situation in the population of students and compare this situation with relevant surveys conducted at the national level. 
On the basis of the data analyzed within the first questionnaire survey, it can be stated that for the students actively involved in the questionnaire survey the motivation for setting up new businesses has a similar distribution as is the case with respondents of the survey conducted by Eurostat on the overall population of the Czech Republic. The results indicate that a comparable assessment can also be identified for anticipated problems associated with activities during the establishment of new businesses. The problem considered the most serious, both by respondents and by students, is the financing of this kind of activity. This indicates the significance of this issue and the importance of closer investigation. As is indicated by the results related to the method of financing, students prefer other means of financing to the use of their own resources. They consider financing through bank credit or loans, both with collateral and without it, and financial support for entrepreneurship from state and public institutions as important sources of financing for activities during the establishment of new businesses.

When investigating entrepreneurial motivation, the concept of push-pull motivators, which divides the causes of setting up a business into reasons of opportunity and reasons of necessity, is widely applied in international scientific literature. Nevertheless, it should be emphasized that there is a huge number of factors which every potential entrepreneur considers and which may affect each individual differently, with different intensity.

Within the second questionnaire survey carried out, it is no surprise that only a minority of respondents are currently engaged in business activities. However, the very high number of students who are counting on establishing and managing their own businesses in the future can be evaluated favourably. It creates a precondition for significant interest in the issue of education and support in the area of entrepreneurship among university students.

The analyses conducted share the conclusion that for the majority of students the most common reason for establishing a business is the desire to make one's own decisions, to be one's own boss. The current generation of university students grew up in a world where (almost) nothing is impossible and success depends primarily on one's own abilities. These values are thus transmitted by students into their ideas about their own entrepreneurship, which can be seen as an independent activity in which a person makes decisions for himself and does not have to submit to authority in the form of an employer. The advantages of the possibility of being one's own boss are valued more highly by students of the Law Faculty.

An equally powerful motive is the desire for profit, which points to the prevalent perception of entrepreneurship as activities linked with higher earnings than is the case in employment.

One problem for most universities is the absence of practical teaching. This was also confirmed in the study presented here, where the respondents cited the fact that they do not have enough experience as the very biggest problem in setting up their own business. For students of FEA in particular, it would therefore be appropriate to introduce compulsory practical subjects which would provide them with an insight into the inner workings of a company, so that it would be easier for them when they eventually embark on constructing their own enterprise.

The second biggest obstacle is the lack of monetary resources. The first questionnaire survey carried out can be used as a basis for evaluating the question of financing an entrepreneurial plan. It thus appears that students will finance the establishment of their business primarily using their own resources, or alternatively by relying on the help of family and friends, or else they will make use of bank loans and credit.

The unfavourable entrepreneurial climate in the form of excessive bureaucracy and administration also appears problematic to students, and in logical terms this represents a problem 
primarily for students without a law education. Strong competition on the market is regarded as an obstacle by students from both faculties without exception.

The research showed the strengths and weaknesses of teaching at the different faculties. By definition, students of the Law Faculty do not have problems with the legal aspects of setting up a business, but they feel there is a lack of information about the business management of an enterprise. This conclusion is based on a preference for individual types of support, where law students in particular requested training for new entrepreneurs. On the other hand, students of economics have a comparative advantage in questions of business management, but they face problems in the area of a high degree of administration and bureaucracy. However, both groups of respondents would appreciate support in the form of tax accounting advice.

In the sense of the fact mentioned in the methodological part of the article, that the questionnaire survey is too restricted, we can conclude that it is reasonable to enrich current subjects at the Faculty of Economics and Administration Masaryk University and develop new subjects connected with the entrepreneurship issue. Thus the restriction of the survey can lead to more useful results for future activities of the research team. Our results indicate that there is interest for entrepreneurship activities among students, that the students are able to take responsibility for their future and that their motivation can be promoted and developed. According to identified problems from student's point of view, there is potential for improvement of the conditions, especially in the theoretical background provided by the university and financial and administrative help provided by state authorities.

\section{Conclusion}

The issue of self-employment in the form of a start-up, a paradigm shift in the behaviour of the younger generation towards self-employment, can be summed up by the words problems and prospects.

The problem is the disproportionately high levels of unemployed young people after they have completed their education at secondary school or university, as it was mentioned in the inroduction of the article. The problém could be denoted as the "golden youth" and its disinclination and lack of attempt to work. The problem is the pseudo involvement of parents in the future development of the younger generation, who often pointlessly encourage their children to study subjects without prospects, just so that they will have peace for a few years. A significant problem is the commitment of the state and local authorities to supporting the independent entrepreneurship of young individuals.

In the beginning it is inevitably necessary to overcome habits, ingrained ideas and overall the paradigm of all of us - society, parents and the younger generation itself - that working isn't abnormal and working for oneself, e.g. in the form of a start-up, the option to employ oneself, is an extraordinary opportunity for further personal development, for the growth of individual wealth, education and the achievement of other important social values.

In theoretical terms, the very thought of establishing one's own business in the form of a start-up is an idea, a creative impulse, whose realization can, however, deliver great value. From the creative impulse comes a project, an entrepreneurial plan, a financial plan. From the speaking or presentation of thoughts comes implementation. The outcome of the project begins to have a greater value than the idea.

A start-up becomes a normal form of entrepreneurship. There is nothing more pleasant than implementing a submitted tender, observing the trend of a growing number of custom- 
ers, issuing receipts and collecting business premiums. In a start-up it isn't necessary to make a profit immediately. However, it is essential for revenue to increase and for a balance to be maintained between expenditure and revenue. This financial balance enables further growth of the business.

Creating a successful model for setting up a business in the form of a start-up is an opportunity to make use of the younger generation's education, an opportunity to develop innovative thinking and personal growth. The problems which young entrepreneurs face can be a challenge for them. Those interested in a start-up are able to overcome obstacles; most of all, however, they prove that they are capable of continually enforcing a model of potential growth with a view to sustainable development.

According to our findings there are students capable to make necessary step and to establish new entrepreneurship in a form of start-up, because they have motivation for such activity. But they need appropriate theoretical background and appropriate help to overcome the obstacles. Universities can provide needed theoretical background and it is state institutions responsibility to provide appropriate help for the absolvents in area of administration and finance.

\section{References}

[1] (e.g. the aforementioned Gilad \& Levine, 1986; Shapero \& Sokol, 1982; Amit \& Muller, 1995 and many others).

[2] \$2 zákona č. 513/1991, obchodní zákoník,

[3] \$420 zákona č. 89/2012 Sb., občanský zákoník, v aktuálním znění.

[4] ADAIR, John Eric. Efektivní motivace. 1st ed. Prague: Alfa Publishing, 2004, 178 pp. Management (Alfa Publishing). ISBN 80-86851-00-1, pp. 14-21.

[5] AMIT, Raphael, Eitan MULLER, Florin PAUN, Leora KLAPPER, Raphael AMIT and Mauro F. GUILLÉN. "PUSH” AND "PULL” ENTREPRENEURSHIP. Journal of Small Business \& Entrepreneurship [online]. 1995, vol. 12, issue 4, p. 131 [cit. 2015-03-28]. Available at: http://www.tandfonline.com/doi/abs/10.1080/08276331.1995.10600505\#.VRaMzfmG_wk

[6] AMORÓS, J., BOSMA, N. Global Entrepreneurship Monitor: Global Report 2013. [online]. [cit. 2015-03-28]. ISBN: 978-1-939242-04-4, p. 32. Available at: http://www.gemconsortium.org/ docs/download/3106

[7] BUCHTOVÁ, Božena. Psychologie pro ekonomy. 1st ed. Brno: Masarykova univerzita v Brně, Ekonomicko-správní fakulta, 2004, 202, [24] pp. ISBN 8021033967, p. 82.

[8] EUROPEAN COMMISSION, Youth unemployement, [online] [cit. 2015-02-11] available at: http://ec.europa.eu/europe2020/pdf/themes/21_youth_unemployment.pdf

[9] EUROPEAN COMMISSION. Survey of Entrepreneurship in Higher Education in Europe: Main report, p. 17. 2008 [online].[cit. 2015-03-27]. Available at: http://ec.europa.eu/enterprise/policies/ sme/files/support_measures/training_education/highedsurvey_en.pdf.

[10] EUROSTAT, Factors of Business Success, (statistics code: fobs_age, fobs_bra, fobs_ent)[online] [cit 2015-03-10] available at: http://ec.europa.eu/eurostat/data/database.

[11] GIACOMIN, Olivier and JANSSEN, Frank and GUYOT, Jean-luc and LOHEST, Olivier: Opportunity and/or necessity entrepreneurship? The impact of the socio-economic characteristics of entrepreneurs. [online]. 2011. p. 4. [cit. 2015-03-28]. Available at: http://mpra.ub.unimuenchen.de/29506/2/MPRA_paper_29506.pdf 
[12] HOUSE OF LORDS. THE COMMISSION'S GREEN PAPER: ENTREPRENEURSHIP IN EUROPE [online]. 2003 [cit. 2015-03-27]. Available at: http://www.publications.parliament.uk/pa/ ld200203/ldselect/ldeucom/142/142.pdf

[13] HUMBERT, Dr. Anne Laure and Prof. Eileen DREW. Gender, Entrepreneurship and Motivational Factors in an Irish Context: Family, Gender and Individual Motivations. International Journal of Gender and Entrepreneurship [online]. 2010, vol. 2, issue 2, 177 pp., pp. 269-270 [cit. 2015-03-28]. Available at: https://www.academia.edu/9006785/Gender_entrepreneurship_ and_motivational_factors_in_an_Irish_context

[14] LUKEŠ, Martin, Martina JAKL and Jan ZOUHAR. MINISTERSTVO PRŮMYSLU A OBCHODU. Global Entrepreneurship Monitor 2013: Podnikatelská aktivita v České republice [online]. 2014 [cit. 2015-03-27]. Available at: http://www.mpo.cz/dokument149362.html, p. 13.

[15] MAYEROVÁ, Marie, Jiř́ RŮŽIČKA and Zbyněk BUREŠ. Psychologie v ekonomické praxi. 1st ed. Plzeň: Západočeská univerzita, 1996, 187 pp. ISBN 80-7082-252-x, p. 64.

[16] PAUKNEROVÁ, Daniela. Psychologie pro ekonomy a manažery. 2nd, revised and updated ed. Prague: Grada, 2006, 254 pp. Manažer. ISBN 80-247-1706-9, p. 173.

[17] REYNOLDS, P.D., W.D. BYGRAVE, E. AUTIO, L.W. COX, and M. HAY, 2002, Global Entrepreneurship Monitor, 2002 Executive Report, Babson College, London Business School and Kauffman Foundation.

[18] ROBICHAUD, Yves, Rolland LEBRASSEUR and K. V. NAGARAJAN. Necessity and Opportunity-Driven Entrepreneurs in Canada: An Investigation into their Characteristics and an Appraisal of the Role of Gender. Journal of Applied Business \& Economics [online]. 2010, year 11, no. 1, p. 14. [cit. 2015-03-28]. Available at: http://m.www.na-businesspress.com/JABE/Jabe111/ RobichaudWeb.pdf

[19] SCHRÖR, H. The Profile of the Successful Enterpreneurs, [online] [cit. 2014-11-27] available at: http://epp.eurostat.ec.europa.eu/cache/ITY_OFFPUB/KS-NP-06-029/EN/KS-NP-06-029-EN. PDF.

[20] SRPOVÁ, Jitka and Václav ŘEHOŘ. Základy podnikání: teoretické poznatky, př́klady a kušenosti českých podnikatelů. 1st ed. Prague: Grada, 2010, 427 pp. Expert (Grada). ISBN 978-80-247-3339-5, p. 35.

[21] YOON, Yooshik and Muzaffer UYSAL. An examination of the effects of motivation and satisfaction on destination loyalty: a structural model. Tourism Management [online]. 2005, vol. 26, issue 1, pp. 45-56 [cit. 2015-03-28]. Available at: http://coromina.webs.com/Yoon_2005_ EffectsMotivationSatisfaction_SEM.pdf str. 46.

[22] ZATHURECKÝ, V.; MARINIČ P. Závěrečná zpráva specifického výzkumu „Analýza potenciálů začínajících podnikü“ (unpublished)
Peter Marinič Viliam Záthurecký Ondřej Špičák

\author{
Masaryk University \\ Faculty of Economics and Administration \\ Department of Corporate Economy \\ marinic@mail.muni.cz \\ zathurecky@econ.muni.cz \\ spicak@mail.muni.cz
}

